\title{
The camerate crinoid Scyphocrinites Zenker in the Upper Silurian or Lower Devonian of New Brunswick, Canada
}

\author{
Stephen K. Donovan ${ }^{1^{*}}$ and Randall F. MilleR ${ }^{2}$ \\ 1. Department of Geology, Naturalis Biodiversity Center, Postbus 9517, 2300 RA Leiden, The Netherlands \\ 2. Steinhammer Palaeontology Laboratory, Natural Science Department, New Brunswick Museum, \\ Saint John, New Brunswick E2K 1E5, Canada \\ ${ }^{*}$ Corresponding author $<$ steve.donovan@naturalis.nl>
}

Date received: 12 June 2014g Date accepted: 27 August 2014

\begin{abstract}
The middle Paleozoic Scyphocrinites Zenker has a distal attachment modified into a globular flotation structure and, uniquely for a crinoid, joined the obligate plankton. Such a flotation structure has been found in the Indian Point Formation (Pridolian to Lochkovian) of Flatlands, northern New Brunswick. It is most likely of Pridolian (Late Silurian) age based on the primitive morphology. The identification is confirmed by the globular gross morphology, multi-plated calcite structure, age and similarity to coeval fossils from Cornwall, southwestern England.

\section{RÉSUMÉ}

Le Paléozoïque moyen Scyphocrinites Zenker a une attache distale modifié dans une structure de flottaison globulaire et, uniquement pour un crinoid, rejoint le plancton obligatoire. Une telle structure de flottaison a été trouvée dans le point de Formation d'Indian (Pridolien à Lochkovien) de Flatlands, le nord du Nouveau-Brunswick. Il est fort probable Pridolien (Silurien supérieur) sur la base de la morphologie primitive. Cette identification est confirmée par la morphologie globulaire brut, la structure de la calcite multi-plaqué, de lầge et de la similarité des fossiles contemporaines de Cornwall, sud-ouest de l'Angleterre.
\end{abstract}

[Traduit par la redaction] 


\section{INTRODUCTION}

Stalked crinoids are typically part of the modern deepwater benthos, but our appreciation of their life orientation and other ecological/paleoecological preferences has been unduly influenced by Nineteenth Century interpretations rather than modern observations (Donovan 2011a). For example, it comes as a surprise to many that some modern stalked crinoids may crawl with their arms (Baumiller and Messing 2007), and the stalkless comatulids can use the same structures for walking or swimming (Meyer and Macurda 1977). They are thus benthic, but certainly not sessile. In the ancient past, some crinoids attached to floating objects such as logs and pursued a pseudoplanktonic lifestyle (Simms 1986; Donovan 2011b); alternatively, in the case of the middle Paleozoic genus Scyphocrinites Zenker, the roots were modified to form a globular flotation device, the lobolith, which made these crinoids true members of the ocean plankton. No other crinoid has ever evolved such a bizarre distal structure (Fig. 1).

The planktonic habit of Scyphocrinites led to it being a facies-crossing taxon in the sedimentary record, distinguishing it from most other Paleozoic crinoids. Further, it has a limited stratigraphic range, occurring in strata that span the Upper Silurian (Pridolian) to Lower Devonian (Lochkovian) boundary, so it is a rare crinoid that can contribute to international biostratigraphic correlation. Its occurrence varies from the gregarious (e.g., Lee 2005) to the diffuse, the latter being the case for the example that we record herein from a Silurian-Devonian boundary section at Flatlands, northern New Brunswick (Fig. 2).
Terminology used for the crinoid endoskeleton follows Moore et al. (1978) and Ubaghs (1978a). Specimens discussed herein are deposited in the Natural Science Department, New Brunswick Museum, Saint John (specimen numbers prefixed by NBMG) or the Geological Museum, University of New Brunswick, Fredericton (UNB).

\section{LOCALITY AND HORIZION}

The fossil was found in a loose block along a road cut of the Indian Point Formation, on the south side of Highway 134 opposite Island View Road, approximately $1 \mathrm{~km}$ east of Flatlands, New Brunswick (Fig. 3). Tumbledout blocks of calcareous mudstone from this locality previously yielded specimens of Medusaegraptus, the intact thalli of a noncalcified macroalgal taxon (LoDuca et al. 2013). Additional fossils in the same blocks include scarce brachiopods, trilobites and crinoid fragments. No trace fossils are present in the blocks.

The Indian Point Formation consists mainly of moderately to strongly calcareous mudstone, fine-grained sandstone and wackestone, and commonly contains fossils of stromatoporoids, brachiopods, trilobites, crinoids and rugose corals (Wilson et al. 2004). Spores and acritarchs (Wilson et al. 2004), as well as brachiopods from the Indian Point Formation in Gaspé, Quebec (Bourque and Lachambre 1980), indicate a Pridolian to middle Lockhovian age. Wilson et al. (2004) reported a U-Pb (zircon) age of $415.0 \pm$ $0.5 \mathrm{Ma}$ for the Squaw Cap Felsite, which intrudes the Indian Point Formation.

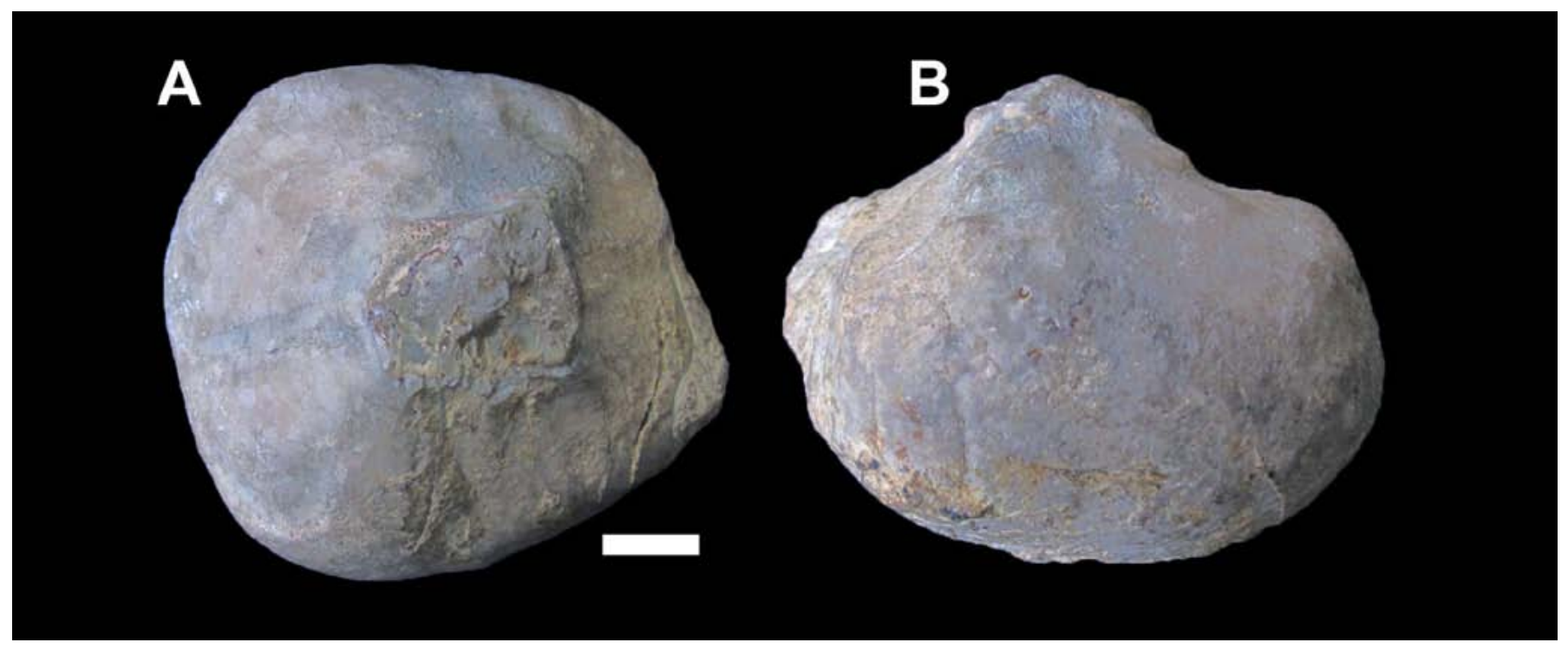

Figure 1. A plated lobolith from UNB, Camarocrinus ulrichi Schuchert 1903, from the Lower Devonian of Oklahoma. (A) Proximal surface, articular facet in center. (B) Lateral view. Specimen uncoated. Scale bar represents $10 \mathrm{~mm}$. 


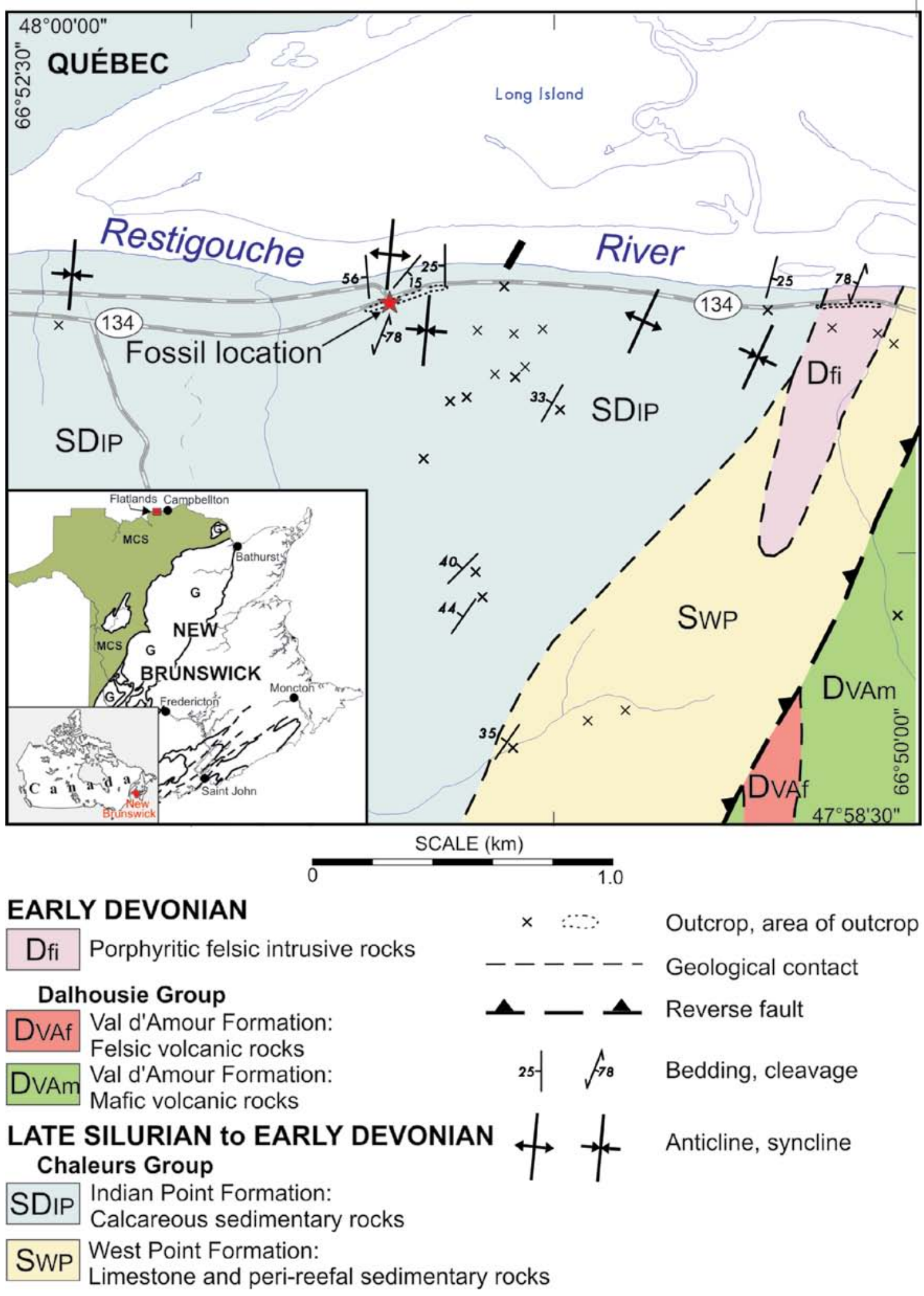

Figure 2. Geological map of Flatlands, New Brunswick. Folded beds of the Late Silurian-Early Devonian Indian Point Formation are exposed along Highway 134. Inset shows location of Flatlands area within New Brunswick. MCS - Middle Paleozoic rocks of the Matapedia Cover Sequence; G - Early Paleozoic rocks of Ganderia terrane. Map courtesy of R. Wilson, New Brunswick Department of Energy and Mines. 


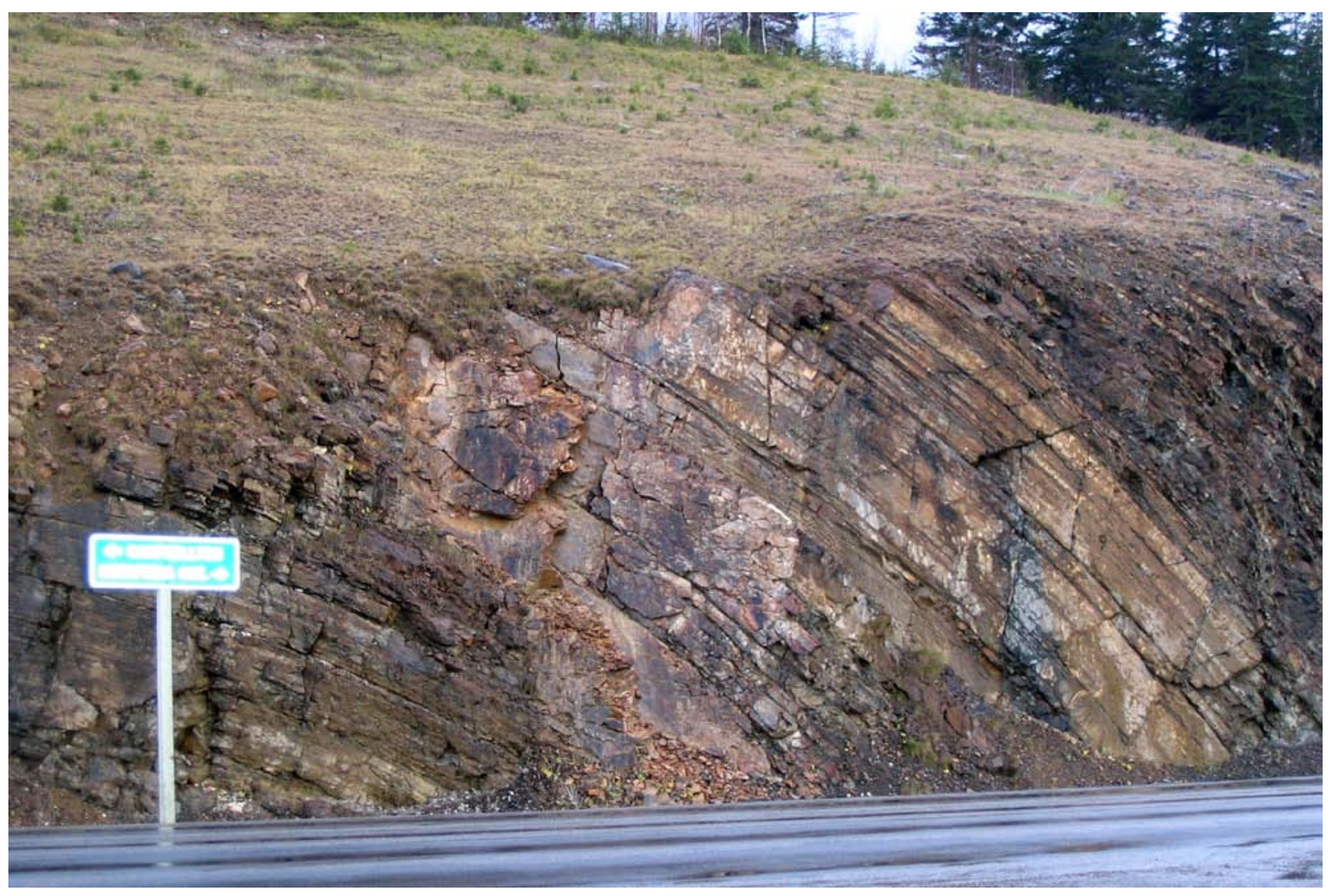

Figure 3. Exposure of the Indian Point Formation on Highway 134, northern New Brunswick. NBMG 16862 was collected from float in the ditch to the right of the sign.

A shallow nearshore marine setting was postulated by Wilson et al. (2004) based on the presence of terrestrial microfossils mixed into a marine environment dominated by brachiopods, crinoids, corals, stromatoporoids and trilobites. Although the rarity of cross-laminated or ripplelaminated beds indicates deposition below fair-weather wave base, Wilson et al. (2004) suggested that water depth may have been only a few meters, as seafloor topography related to reefs in the West Point Formation may have acted to baffle wave and current energy. This interpretation is consistent with the presence of Medusaegraptus (LoDuca et al. 2013).

\section{SYSTEMATIC PALEONTOLOGY}

Class Crinoidea J.S. Miller 1821

Subclass Camerata Wachsmuth and Springer 1885

Order Monobathrida Moore and Laudon 1943

Family Scyphocrinitidae Jaekel 1918

Genus Scyphocrinites Zenker 1833
TYPE SPECIES. Scyphocrinites elegans Zenker 1833, p. 25 , by monotypy (Ubaghs 1978b, p. T489).

OTHER SPECIES. Webster (2003) listed 15 nominal species of Scyphocrinites (including Camarocrinus Hall 1879) that he regarded as valid.

DIAGNOSIS OF LOBOLITH. (After Ubaghs 1978b, p. T489.) "Column ending distally either in small encrusting root or (more typically) in large bulbous chambered structure designated separately as Lobolithus or Camarocrinus with walls of minute irregular plates, having their origin in bifurcations and modifications of innumerable rootbranches; axial canal of stem quinquelobate to sharply quinquestellate."

REMARKS. As noted by Lee (2005), in light of the pivotal research of Haude (1992), loboliths of Scyphocrinites fall into two morphological groups of broadly similar gross morphology. The primitive condition is represented by the so-called cirrus (more correctly these are inflexible radices, not flexible cirri; Donovan 1993) loboliths, formed from amalgamated branching "roots"; this group includes the 
specimen from Flatlands (Fig. 4). Cirrus loboliths had been considered to be mainly limited to the Pridolian (e.g., Haude 1992; Lee 2005, p. 334), but the primitive condition is now known also from the lowermost Lochkovian (Donovan and Lewis 2009). The more robust plated loboliths (Fig. 2) range from the uppermost Pridolian to lowermost Lochkovian.

Crinoids remain poorly known from the Silurian of New Brunswick. Specimens in the NBM are currently being described by the authors (research in progress) and newly collected material, provisionally assigned to columnal morphospecies Cyclocyclicus (col.) geoffnewalli Fearnhead and Donovan 2007, is being described by one of us (SD) and D.G. Keighley (University of New Brunswick).
RANGE. Upper Silurian (Pridolian) to Lower Devonian (lowermost Lochkovian), global in distribution (Haude 1992).

\section{Scyphocrinites sp.}

(Fig. 4)

MATERIAL, LOCALITY, AND HORIZON. A single specimen, NBMG 16862, from Flatlands, New Brunswick. Collected from a tumbled-out block along the south side of Highway 134 (Figs. 1-2), opposite Island View Road (NTS Map 21 O/15; 47 $59.47^{\prime} \mathrm{N} ; 66^{\circ} 51.47^{\prime} \mathrm{W}$ ). Indian Point Formation, Pridolian (Upper Silurian) or, less probably,

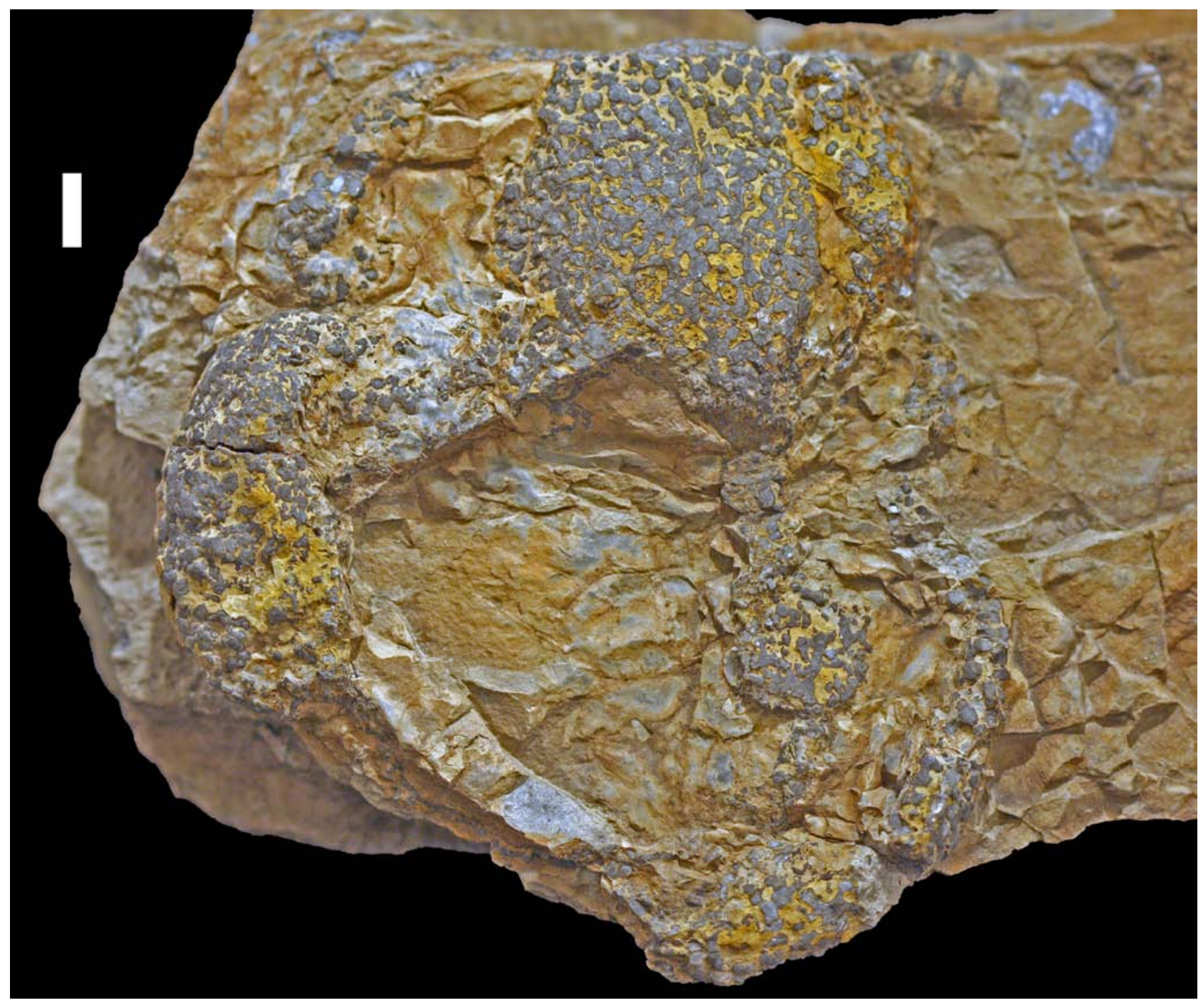

Figure 4. NBMG 16862, Scyphocrinites sp. from the Indian Point Formation, northern New Brunswick. The lobolith has collapsed, but is apparent as the pattern of small grey plates arrayed in an approximately circular pattern. Much of the center was lost before collection and the specimen is most complete just above this region. Compare with Fig. 1 which, while not exactly identical, has a similar gross morphology to NBMG 16862. Specimen uncoated. Scale bar represents $10 \mathrm{~mm}$. 
Lockhovian (Lower Devonian); see above. Collected by RFM, September 10, 2012.

DESCRIPTION. Irregularly-shaped clast derived from a bed $60-65 \mathrm{~mm}$ in thickness, composed of well-lithified, grey, micaceous, fine-grained sandstone, weathering brown. The lobolith is collapsed and preserved as an irregularly rounded area about $132 \times 113 \mathrm{~mm}$. The rim of this area is continuous, more or less thickened; more centrally, less than half of the area is covered by articulated echinoderm plates, these being either lost by exfoliation or concealed by sandstone. Echinoderm plates contrast with the brownweathered rock because of their medium to dark grey coloration (Fig. 4). Plates are numerous, rounded in outline and swollen, in lateral contact (where apparent) and forming regular to irregular plate aggregations. Attachment for the column is not preserved and there are no conspecific columnals or pluricolumnals preserved on adjacent bedding surfaces. Other bioclasts on more or less the same bedding plane include solitary rugose corals, brachiopods (including a rhynchonellid) and some poorly preserved crinoid debris. Other, unregistered specimens from the same site, now in the same drawer, include what may be columnals and pluricolumnals of Scyphocrinites sp.

REMARKS. Four lines of evidence support our identification of this peculiar specimen as a lobolith of Scyphocrinites. The globular gross morphology is reminiscent of how similarly shaped, weakly sutured structures such as Paleozoic echinoid tests collapse in the rock record (Lewis and Emson 1982). The multi-plated calcite structure is certainly echinodermal. The age of the Indian Point Formation is limited, but includes the entire range of Scyphocrinites (Haude 1992). And these data are supported by the close morphological similarity of NBMG 16862 to other occurrences of multi-plated loboliths (discussed below).

We therefore interpret this specimen as an incomplete, partly collapsed and partly deformed lobolith of Scyphocrinites sp. The mode of preservation is reminiscent of loboliths originally described by Bather (1907) from the Lochkovian of Cornwall, southwestern England. The Cornish specimens are so poorly preserved that they were not figured in Bather's report and have only been illustrated more recently (Donovan and Lewis 2009, fig. 1; Donovan et al. 2012, text-fig. 77; Donovan and Fearnhead 2014, pl. 15). The principal difference between these occurrences is lithology, as the Cornish specimens are preserved in limestone. This difference in occurrence is not surprising in a crinoid that is planktonic; Simms (1986, pp. 476-477, table 1) demonstrated similar facies-crossing distributions of pseudoplanktonic crinoids from the Jurassic.

Our new record of Scyphocrinites sp. is notable because Silurian and Devonian crinoids remain poorly known from eastern Canada. Previous reports have demonstrated the utility of the crinoids from this region for studies of paleoecology and morphology (Donovan and Pickerill 1995a, b). Part of the reason why crinoids from this area and interval have been ignored is undoubtedly taphonomic. Few of the crinoids known from this region are well preserved, again with the notable exception of material from Anticosti Island, and there is a resistance to expending energy on fragmentary fossils when more complete, aesthetically more pleasing and easier to identify taxa, such as brachiopods, trilobites and corals, are available. This is a common problem with Paleozoic crinoids (see, for example, Donovan 2013) and, in the absence of more complete material, it is only by studying incomplete specimens like NBMG 16862 that our knowledge of their true biodiversity and paleogeography will be completed.

\section{ACKNOWLEDGMENTS}

SKD gratefully acknowledges the award of a G.F. Matthew Research Grant for 2013 by the New Brunswick Museum, which facilitated this research in May 2014. Naturalis Biodiversity Center, Leiden, provided further support and further facilitated a research visit to the New Brunswick Museum in May 2014. We thank Fiona Fearnhead (the Natural History Museum, London) and Christopher Paul (University of Bristol) for their positive comments in reviewing the manuscript. Thanks to Reg Wilson, New Brunswick Geological Surveys Branch, Department of Energy and Mines for permission to reproduce Fig. 2.

\section{REFERENCES}

Bather, F.A. 1907. The discovery in west Cornwall of a Silurian crinoid characteristic of Bohemia. Transactions of the Royal Geological Society of Cornwall, 13, pp. 191197.

Baumiller, T.K. and Messing, C.G. 2007. Stalked crinoid locomotion, and its ecological and evolutionary implications. Palaeontologia Electronica, 10, 10 p.

Bourgue, P.-A. and Lachambre, G. 1980. Stratigraphie du Silurien et du Dévonien basal du sud de la Gaspésie, Québec. Direction générale de la recherche géologique et minérale. Ministère de l'énergie et des resources, Québec, ES-30, 123 p.

Donovan, S.K. 1993. Contractile tissues in the cirri of ancient crinoids: criteria for recognition. Lethaia, 26, pp. 163-169. http://dx.doi.org/10.1111/j.1502-3931.1993. tb01808.x

Donovan, S.K. 2011 a. The poorly illustrated crinoid. Lethaia, 44, pp. 125-135. http://dx.doi.org/10.1111/j.15023931.2011.00267.x 
Donovan, S.K. 2011b. Spineless displays or why inaccurate restorations of fossil invertebrates discredit our museums. Geological Curator, 9, pp. 279-284.

Donovan, S.K. 2013. Where are all the crinoids? An enigma of the Lower Carboniferous (Mississippian) White Peak of midland England. Geology Today, 29, pp. 108-112. http://dx.doi.org/10.1111/gto.12010

Donovan, S.K. and Fearnhead, F.E. 2014. The British Devonian Crinoidea. Part 1, introduction and Camerata. Monograph of the Palaeontographical Society, London, 168 (643): i-viii, 1-55.

Donovan, S.K. and Lewis, D.N. 2009. The mid-Palaeozoic camerate crinoid Scyphocrinites Zenker in southwest England. Bulletin of the Mizunami Fossil Museum, 35, pp. 97-100.

Donovan, S.K. and Pickerill, R.K. 1995a. Crinoid columns preserved in life position in the Silurian Arisaig Group of Nova Scotia, Canada. Palaios, 10, pp. 362-370. http:// dx.doi.org/10.2307/3515161

Donovan, S.K. and Pickerill, R.K. 1995b. A camerate crinoid from the Upper Silurian (Ludlow) Moydart Formation of Nova Scotia, Canada. Atlantic Geology, 31, pp. 81-86.

Donovan, S.K., Widdison, R.E., Lewis, D.N., and Fearnhead, F.E. 2012. The British Silurian Crinoidea. Part 3, addendum to parts 1 and 2, Camerata and columnals. Monograph of the Palaeontographical Society, London, 166 (638), pp. 135-259.

Fearnhead, F.E. and Donovan, S.K. 2007. A robust crinoid from the Llandovery (Lower Silurian) of Norbury, Shropshire: systematics, palaeoecology and taphonomy. Proceedings of the Geologists' Association, 118, pp. 339345.

Hall, J. 1879. Notice of some remarkable crinoid forms from the lower Helderberg Group. New York State Museum, Annual Report, 28, pp. 205-210.

Haude, R. 1992. Scyphocrinoiden, die Bojen-Seelilien im hohen Silur-tiefen Devon. Paleontographica Abteilung A, Palaeozoologie und Stratigraphie, 222, pp. 141-187.

Jaekel, O. 1918. Phylogenie und System der Pelmatozoen. Paläeontologisches Zeitschrift, 3 (1), pp. 1-128. http:// dx.doi.org/10.1007/BF03190413

Lee, C.P. 2005. Discovery of plate-type scyphocrinoid loboliths in the uppermost Prídolían-lowermost Lochkovian Upper Setul limestone of Peninsular Malaysia. Geological Journal, 40, pp. 331-342. http:// dx.doi.org/10.1002/gj.1008

Lewis, D.N. and Ensom, P.C. 1982. Archaeocidaris whatleyensis sp. nov. (Echinoidea) from the Carboniferous Limestone of Somerset, and notes on echinoid phylogeny. Bulletin of the British Museum (Natural History), Geology, 36, pp. 77-104.

LoDuca, S.T., Miller, R.F., and Wilson, R.A. 2013. Medusaegraptus (Chlorophyta, Dasycladales) from the Pridolian to middle Lochkovian Indian Point Formation,
New Brunswick, Canada. Atlantic Geology, 49, pp. 118125. http://dx.doi.org/10.4138/atlgeol.2013.005

Meyer, D.L. and Macurda, D.B., Jr. 1977. Adaptive radiation of the comatulid crinoids. Paleobiology, 3, pp. 74-82.

Miller, J.S. 1821. A natural history of the Crinoidea or lilyshaped animals, with observation on the genera Asteria, Euryale, Comatula and Marsupites. C. Frost, Bristol, 150 p.

Moore, R.C. and Laudon, L.R. 1943. Evolution and classification of Paleozoic crinoids. Geological Society of America Special Paper, 46, 153 p.

Moore, R.C. with additions by Ubaghs, G., Rasmussen, H.W., Breimer, A., and Lane, N.G. 1978. Glossary of crinoid morphological terms. In Treatise on Invertebrate Paleontology. Part T. Echinodermata 2(1). Edited by R.C. Moore and C. Teichert. Geological Society of America and University of Kansas Press, Boulder and Lawrence, pp. T229, T231, T233-T242.

Schuchert, C. 1903. On new Siluric Cystoidea, and a new Camarocrinus. The American Geologist, 32, pp. 230-240.

Simms, M.J. 1986. Contrasting lifestyles in Lower Jurassic crinoids: a comparison of benthic and pseudopelagic Isocrinida. Palaeontology, 29, pp. 475-493.

Ubaghs, G. 1978a. Skeletal morphology of fossil crinoids. In Treatise on Invertebrate Paleontology. Part T. Echinodermata 2(1). Edited by R.C. Moore and C. Teichert. Geological Society of America and University of Kansas Press, Boulder and Lawrence, pp. T58-T216.

Ubaghs, G. 1978b. Camerata. In Treatise on Invertebrate Paleontology. Part T. Echinodermata 2(1). Edited by R.C. Moore and C. Teichert. Geological Society of America and University of Kansas Press, Boulder and Lawrence, pp. T408-T519.

Wachsmuth, C. and Springer, F. 1885. Revision of the Palaeocrinoidea, part III, section 1. Discussion of the classification and relations of the brachiate crinoids, and conclusion of the generic descriptions. Proceedings of the Academy of Natural Sciences of Philadelphia for 1885, pp. 223-364.

Webster, G.D. 2003. Bibliography and index of Paleozoic crinoids, coronates, and hemistreptocrinoids 1758-1999. Geological Society of America Special Paper, 363. http:// crinoid.gsajournals.org/crinoidmod

Wilson, R.A., Burden, E.T., Bertrand, R., Asselin, E., and McCracken, A.D. 2004. Stratigraphy and tectonosedimentary evolution of the Late Ordovician to Middle Devonian Gaspé Belt in northern New Brunswick: evidence from the Restigouche area. Canadian Journal of Earth Sciences, 41,pp. 527-551. http://dx.doi.org/10.1139/ e04-011

Zenker, J.C. 1833. Organische Reste (Petrefacten) aus der Altenburger Braunkohlen-Formation etc. Beiträge zur Naturgeschite Urwelt, Jena, viii+ 67 p.

Editorial responsibility: Robert A. Fensome 